\title{
CONSTRUCCION DE UNA GENOTECA DE PLASMODIUM FALCIPARUM EN EL FAGO LAMBDA EMBL-4 Y AISLAMIENTO DE CLONOS QUE CONTIENEN LA SECUENCIA REPETITIVA DE 692 PARES DE BASES (PFCOL692)
}

\begin{abstract}
Jorge Contreras', Moisés Wasserman?
Se construyó una genoteca de Plasmodium falciparum en el fago lambda EMBL-4. Se aislaron 28 clonos con insertos entre 14.000 y 23.000 pares de bases $(\mathrm{pb})$ que hibridizan con la secuencia PFCOL69, utilizando como sonda el plásmido recombinante pUC18 que contiene un fragmento de DNA correspondiente a una nueva secuencia repetitiva del parásito (PFCOL692). Se describe la metodología usada para la construcción de la genoteca y para el aislamiento de los clonos y se discute su importancia en el estudio de la biología molecular del parásito.
\end{abstract}

\section{INTRODUCCION}

Para estudios epidemiológicos de malaria se ha venido intentando desarrollar técnicas que permitan el manejo simultáneo de un gran número de muestras y el diagnóstico específico para cada una de las especies de Plasmodium. Una estrategia ha sido la utilización de sondas de DNA construidas con base en secuencias repetitivas dentro del genoma (1) y en RNA ribosomal (2); sin embargo, ningún estudio ha aportado resultados definitivos de manejo de muestras, sensibilidad y especificidad.

Hasta el momento el estudio de las secuencias repetidas en el Plasmodium ha sido orientado con fines diagnósticos, nada se ha publicado sobre su función. Trabajos en el Grupo de Bioquímica del Instituto Nacional de Salud $(3,4,5)$ han llevado al aislamiento de un fragmento de DNA de 1384 pb que contiene dos copias de una secuencia de 692 y se repite 60 veces en el genoma del parásito (datos no publicados), se encuentra en 13 de los cromosomas (5) y es diferentea las secuencias repetidas de Plasmodium falciparum reportadas ( $1,6,7,8$ y 9). La identificación de la secuencia se llevó a cabo en una genoteca construida utilizando el plásmido pUC18; con el estudio de clonos obtenidos de una genoteca en el fago lambda EMBL-4 que permite la clonación de fragmentos de mayor tamaño, conoceremos mejor la estructura y la localización y se podrán plantear hipótesis sobre la función del PFCOL692.

\section{MATERIALES Y METODOS}

\section{Aislamiento del DNA de Plasmodium falciparum \\ Se aisló el DNA a partir de un cultivo asincrónico de la cepa FCB-2 con parasitemias entre el 5 y $10 \%$ (10). Se liberó el parásito de los eritrocitos mediante lisis con saponina (11). Se lisó el pará- sito incubando en un buffer que contiene: Tris 10}

1 Universidad Nacional de Colombia

2 Grupo de Bioquimica, Instituto Nacional de Salud 
$\mathrm{mM}$, EDTA pH:8 $25 \mathrm{mM}$, SDS 0,5\% y proteinasa $\mathrm{K} 0,2 \mathrm{mg} / \mathrm{ml}$ durante 12 horas a $50^{\circ} \mathrm{C}$ (12). Se purificaron los ácidos nucleicos mediante extracciones orgánicas suaves con fenol y cloroformo y diálisis durante 24 horas contra TE (Tris $\mathrm{pH}: 7,5$ $1 \mathrm{mM}$, EDTA pH:8 0,1 mM). La concentración de DNA se determinó espectrofotométricamente a $260 \mathrm{~nm}$ y el estado del DNA después de la extracción se visualizó mediante electroforesis en gel de agarosa (AGE) en presencia de bromuro de etidio e iluminando con luz ultravioleta de $302 \mathrm{~nm}$ de longitud de onda.

\section{Digestión parcial y separación por tamaño del DNA de Plasmodium falciparum}

Se utilizaron brazos del fago lambda-EMBL-4 digerido con Bam HI (AMERSHAM) (13); se seleccionóla enzima Sau $3 A$ I(PROMEGA), isoesquisómero de la enzima Bam $\mathrm{HI}$, que reconoce y corta en la secuencia GATC. Se probaron concentraciones de enzima entre 0,05 y 0,5 unidades por ug de DNA y tiempos entre 5 y 20 minutos. Se hizo digestión parcial de 50 a 100 ug de DNA. Las condiciones de digestión escogidas fueron aquéllas en las cuales una tercera parte del DNA digerido tenía un tamaño superior a 23.000 , una tercera parte inferior a 14.000 y la otra entre 14.000 y $23.000 \mathrm{pb}$, esto le confiere una alta representatividad al DNA seleccionado para la clonación.

EI DNA se separó por tamaño mediante centrifugación en gradientes de sacarosa del 10 al $40 \%$ a $85.000 \mathrm{~g}, 30$ horas y $20^{\circ} \mathrm{C}(14)$. La capacidad del vector oscila entre 9.000 y $23.000 \mathrm{pb}$; se seleccionaron las fracciones del gradiente que contenían fragmentos de DNA entre 14.000 y 23.000 pb; el DNA de cada fracción se observó mediante AGE; no se tomaron fragmentos de tamaño inferior a $14.000 \mathrm{pb}$ para evitar eventos de recombinación entre segmentos separados en el genoma.

\section{Ligación, empaquetamiento del DNA e infección y crecimiento de los fagos recombinantes}

La ligación del DNA del vector (EMBL-4) y del DNA de parásito se hizo utilizando la enzima T4 ligasa $(B R L)(15,16)$; se ensayaron ligaciones con relaciones (P/P) vector: DNA de parásito de 10:1, $5: 1$ y 1:5, según lo recomendado (13). La reacción de ligación se hizo con 5 unidades de ligasa por ug de DNA durante 4 horas a $16^{\circ} \mathrm{C}$ en un buffer $50 \mathrm{mM}$ de Tris $\mathrm{pH}: 7.5,10 \mathrm{mM}$ de $\mathrm{MgCl} 2$, $10 \mathrm{mM}$ de Ditiotreitol, $1 \mathrm{mM}$ de ATP, $5 \%$ de polietilenglicol y $500 \mathrm{ug} / \mathrm{ml}$ de albúmina sérica bovina .

EI DNA ligado fue empacado en las cabezas y colas del fago, se utilizaron extractos de empaquetamiento obtenidos comercialmente (PROMEGA); se agregó el DNA producido por la reacción de ligación al extracto de empaquetamiento y se incubó durante 2 horas a $20^{\circ} \mathrm{C}(17)$. Se hace infección de bacterias de la cepa NM538 de $E$. coli mezclando diluciones de los fagos con bacterias e incubando $30 \mathrm{~min}$ a $37^{\circ} \mathrm{C}$. La cepa NM 538 se creció en un medio que contiene $0,2 \%$ de maltosa para inducir la expresión en las bacterias del receptor para maltosa el cual es utilizado por el fago para la infección (18). Se tomó la suspensión de bacterias infectadas, se mezcló con Top-agarosa (medio LB, 0,2\% de maltosa, 0,7\% de agarosa y $10 \mathrm{mM}$ de MgSO4), se esparció sobre cajas de LB-agar al $1 \%$ y se incubó toda la noche a $37^{\circ} \mathrm{C}$. Al día siguiente hubo crecimiento de un césped bacteriano con áreas de lisis correspondientes a fagos recombinantes; estas áreas (placas o clonos) fueron contadas y se estableció el número de placas por ug de DNA empaquetado.

\section{Filtros réplica de la genoteca e hibridización con la secuencia PFCOL692}

Se hizo crecimiento de 5.000 placas de fago recombinante en una caja de petri de $140 \mathrm{~mm}$ de diámetro, fueron transferidas a membranas de nylon (filtros réplica) (19). Se hicieron filtros por duplicado de cada caja, se denaturó el DNA transferido colocando los filtros (con el lado por donde se encuentra el DNA hacia arriba) sobre un papel humedecido con una solución $0,5 \mathrm{~N}$ de $\mathrm{NaOH}$ y $1,5 \mathrm{M}$ de $\mathrm{NaCl}$ durante 5 minutos. Se neutralizaron colocándolos de manera similar sobre un papel con una solución $0,5 \mathrm{M}$ de Tris $\mathrm{pH}: 7,5$ y $3 \mathrm{M}$ de $\mathrm{NaCl}$ por 5 minutos y se hizo un 
lavado en la misma forma con $2 x$ SSPE (20x SSPE: $3 \mathrm{M} \mathrm{NaCl}, 0,2 \mathrm{M}$ de $\mathrm{Na}_{2} \mathrm{HPO} 4 . \mathrm{H} 2 \mathrm{O}$ y $20 \mathrm{mM}$ de EDTA pH:8,0). Se fijó el DNA exponiendo la membrana durante 5 minutos a luz ultravioleta.

Como sonda se utilizó el plásmido recombinante pUC18 con un fragmento de 1384 pb que contiene 2 copias de la secuencia repetitiva. Se hizo marcación de la sonda utilizando el método de random primer (20) utilizando ATP marcado en el fosfato con ${ }^{32} \mathrm{P}$.

Se hizo prehibridización de los filtros incubándolos una hora a $40^{\circ} \mathrm{C}$ en una solución $6 \times$ SSPE, formamida al $50 \%$, Denhardt's $5 x$ (Denhardt's 100x: $2 \% \mathrm{p} / \mathrm{v}$ de ficoll, $2 \% \mathrm{p} / \mathrm{v}$ polivinilpirrolidona y $2 \% \mathrm{p} / \mathrm{v}$ de albúmina sérica bovina fracción $\mathrm{V}$ ), sulfato de dextrán al 5\%, SDS 0,1\% y DNA de esperma de salmón $100 \mathrm{ug} / \mathrm{ml}$; se agregó la sonda denaturada por calentamiento a $100^{\circ} \mathrm{C}$, la concentración de sonda fue de 1 a $2 \mathrm{ng} / \mathrm{ml}$ (106 cpm/ $\mathrm{ml}$ ), se incubó 18 horas a $40^{\circ} \mathrm{C}$. Se hizo un lavado en 6 XSPE- $0,1 \%$ SDS, uno en $2 \times$ SSPE- $0,1 \%$ SDS y 2 en $0,1 \times$ SSPE- $0,1 \%$ SDS, cada uno de 15 minutos a $42^{\circ} \mathrm{C}$. Se seleccionaron los clonos que produjeron señal por duplicado; se resuspendieron en 500 ul de SM (10 mM de Tris $\mathrm{pH}: 7.5,10$ $\mathrm{mM}$ de $\mathrm{MgSO}_{4}$, y $0,01 \%$ de gelatina) y se almacenaron a $4^{\circ} \mathrm{C}$. A partir de las suspensiones preparadas en SM, se hizo infección y crecimiento de tres de los clonos aislados y se reconfirmó por hibridización su homología con la secuencia repetitiva.

\section{RESULTADOS Y DISCUSION}

\section{Extracción del DNA de Plasmodium falciparum}

Se obtuvo DNA de alto peso molecular libre de RNA (figura1). Se observa que el DNA extraído presenta una movilidad electroforética inferior al marcador de tamaño de 24.000 $\mathrm{pb}$, el tamaño exacto es difícil de establecer debido a que en el sistema utilizado el comportamiento del DNA extraido lo presentan fragmentos que tienen un tamaño que oscila entre millones a $30.000 \mathrm{pb}$.

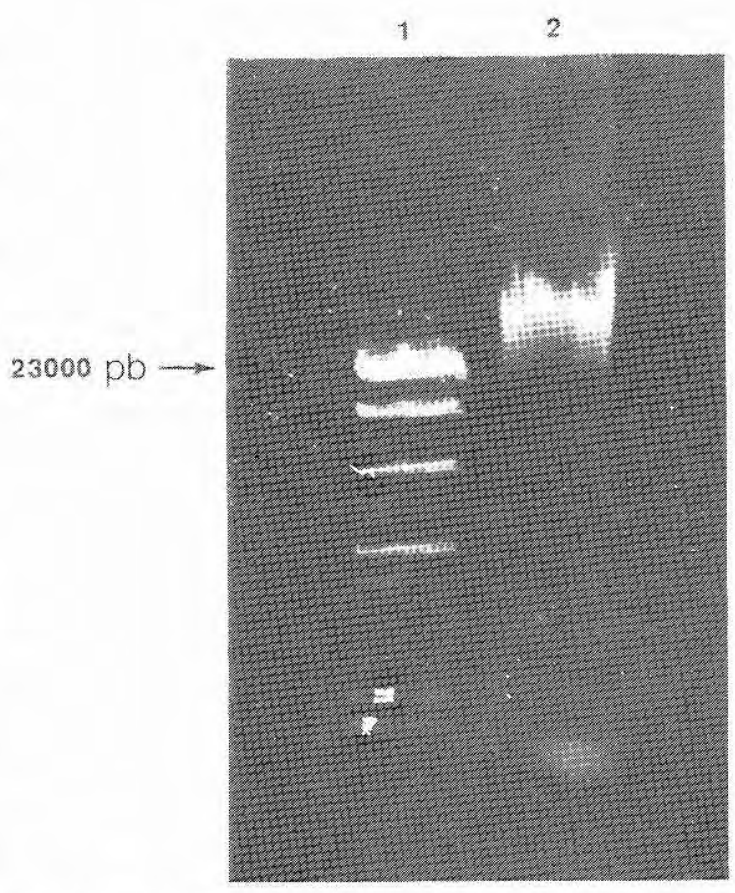

Figura 1. El carril 1 muestra el marcador de tamaño producido por la digestión del fago lambda digerido con la enzima Hind III. El carril 2 de la fotografía de la electroforesis muestra el DNA del parásito luego de la diálisis.

En este protocolo no se utilizó precipitación etanólica para evitar la ruptura del DNA. Durante la extracción de DNA no fue necesario realizar procedimientos para separar el RNA (tratamiento con RNAsa o gradiente en $\mathrm{CsCl}$ ). Durante el período de incubación para que ocurra la lisis de los parásitos, el RNA se degrada completamente, lo cual podría ser debido a una actividad de RNAsa basal alta. Aunque durante el desarrollo asexual no ha sido descrito, el parásito en su diferenciación del estadio sexual al asexual hace un recambio completo del RNA ribosomal para lo cual utiliza una alta actividad de RNAsa.

En la valoración espectrofotométrica se obtuvo un índice de densidad óptica a $260 \mathrm{~nm}$ sobre $280 \mathrm{~nm}$ de 2,1; éste es un dato que difiere del dato reportado como criterio de pureza para DNA, 1,8 (13), la diferencia debe ser atribuida a que el contenido en bases adenina y timina del parásito es superior al $80 \%$, y la adenina es la base que presenta el mayor coeficiente de extinción molar a $260 \mathrm{~nm}$ incrementando de esta manera el valor de la relación de densidad óptica de 260 sobre $280 \mathrm{~nm}$. Para DNA de Plasmodium 
falciparum esta relación se obtiene de rutina en el laboratorio incluso utilizando métodos de separación tan estrictos como gradientes de cloruro de cesio.

\section{Digestión parcial de DNA de Plasmodium falciparum y su separación por tamaño}

El sistema de clonación utiliza el vector EMBL-4 el cual es un derivado del fago lambda. Para poder empaquetar un DNA adecuadamente dentro de las cabezas y colas es necesario que tenga un tamaño que oscile entre el 85 y $105 \%$ del tamaño del lambda natural (48.000 pb), los brazos del EMBL-4 utilizados en este trabajo presentan tamaños de 14.000 y 9.000 pb, esto permite insertar fragmentos que tengan un tamaño entre 9.000 y $23.000 \mathrm{pb}$. La selección de fagos recombinantes se hace por que solo crecerán aquellos fagos que recibieron un DNA del parásito del tamaño adecuado. Para evitar problemas de recombinación interna entre fragmentos de DNA del parásito distantes en el genoma, sólo se seleccionaron para la ligación fragmentos entre 14.000 y $23.000 \mathrm{pb}$. La selección de estos tamaños nos permite tener una representatividad del $99 \%$ del genoma en 6.000 placas, si incluyéramos en la clonación los fragmentos de tamaño inferior a $14.000 \mathrm{pb}$ se necesitarían 9000 placas. Se seleccionó la digestión con 0,1 unidades de Sau 3Al por ug de DNA y un tiempo entre 12 y 20 minutos (figura 2).

Para obtener el DNA con un tamaño entre 14.000 y 23.000 pb se seleccionaron las fracciones 14-16 del gradiente de sacarosa (figura 3).

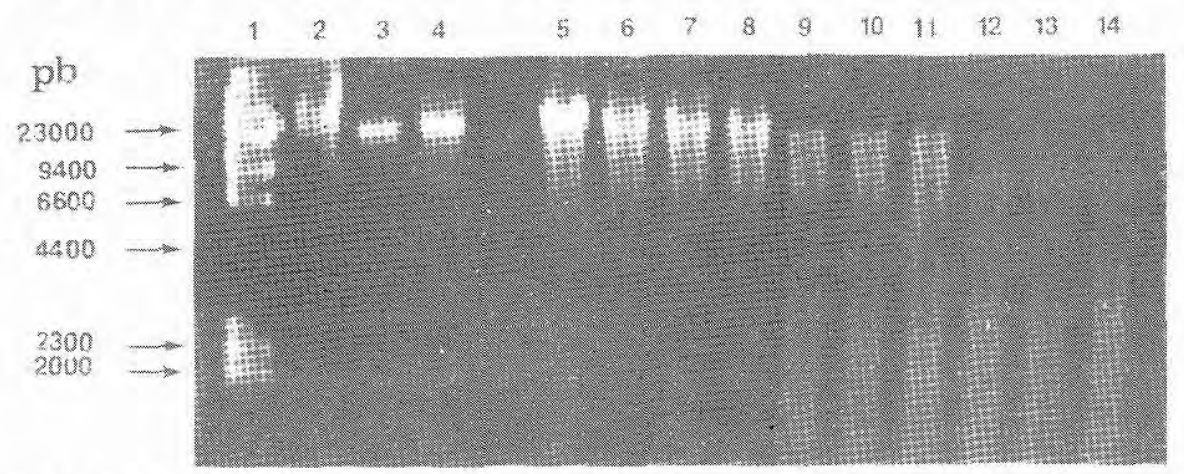

Figura 2. Fotografía de una electroforesis donde se muestran los resultados de la estandarización de la digestión del DNA con Sau 3AI. Carril 1, marcador de tamaño lambda Hind III; carril 2, DNA sin digestión; carriles 3,4 y 5, digestión con 0,05 unidades por ug durante 5,12 y 20 minutos respectivamente; carriles 6,7 y 8 , digestión con 0,1 unidades por ug durante 5,12 y 20 minutos respectivamente; carriles 9,10 y 11 , digestión con 0,2 unidades por ug durante 5,12 y 20 minutos respectivamente; carriles 12. 13 y 14 , digestión con 0,4 unidades por ug durante 5,12 y 20 minutos respectivamente.

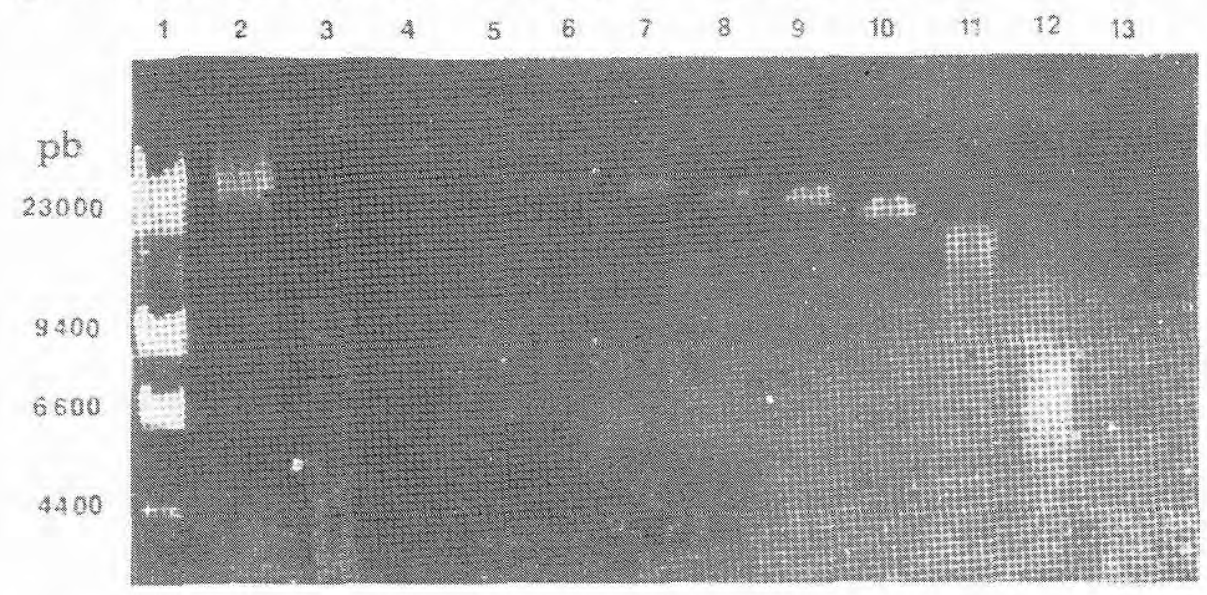

Figura 3. Fotografía de la electroforesis de las fracciones del gradiente de sacarosa. Carril 1, marcador de tamaño lambda Hind III; carril 2. DNA sin digestión; carril 3, DNA digerido parcialmente con Sau 3Al; carriles 4 al 13, fracciones del gradiente. 


\section{Ligación DNA y empaquetamiento y crecimiento de los fagos recombinantes}

De las proporciones $(p / p)$ DNA de vector: DNA de parásito ensayadas el mayor título fue producido por la proporción 10:1 con $1 \times 10^{6}$ fagos por ug de DNA empaquetado, para las otras estuvo entre $10^{4}$ y $10^{5}$. Este hecho muestra cómo la utilización de una cantidad de DNA de parásito a clonar mayor de $1 / 10(\mathrm{p} / \mathrm{p})$ con relación a la cantidad de DNA de vector produce eventos de recombinación entre fragmentos del parásito $y$ debido a que se producen tamaños superiores a $14.000 \mathrm{pb}$, el DNA de fago tendrá un tamaño superior al $105 \%$ del tamaño natural disminuyendo la eficiencia de empaquetamiento.

\section{Hibridización de las réplicas de la genoteca con la secuencia PFCOL692 marcada radioactivamente}

En los ensayos de hibridización de los filtros réplica con la secuencia PFCOL692 fueron identificados 28 clonos que daban señal por duplicado. Con los clonos aislados (figura 4) se podrán iniciar estudios de mapeo de restricción, hibridización y secuenciación que permitan conocer las secuencias vecinas a PFCOL692 en el genoma, conocer mejor la estructura y plantear hipótesis sobre la función de esta secuencia repetitiva. El hecho de que 28 clonos de 5.000 evaluados presenten homología con PFCOL692 nos permite afirmar que aproximadamente el $0,56 \%$ del genoma del parásito está constituido por esta secuencia; estos datos son parecidos a los obtenidos según el número de copias por genoma (60) donde el porcentaje sería del $0,52 \%$ (datos no publicados).

Debido a que la enzima utilizada para digestión del DNA sólo reconoce cuatro pares de bases (GATC), a las condiciones de digestión utilizadas y teniendo en cuenta que el vector seleccionado nos permite la clonación de fragmentos de DNA entre 14.000 y 23.000 pb, en una genoteca de las características de la construida, se garantiza alta representatividad del genoma del parásito, $99 \%$ en aproximadamente 6.000 fagos (15), facilitando en gran medida la manipu-

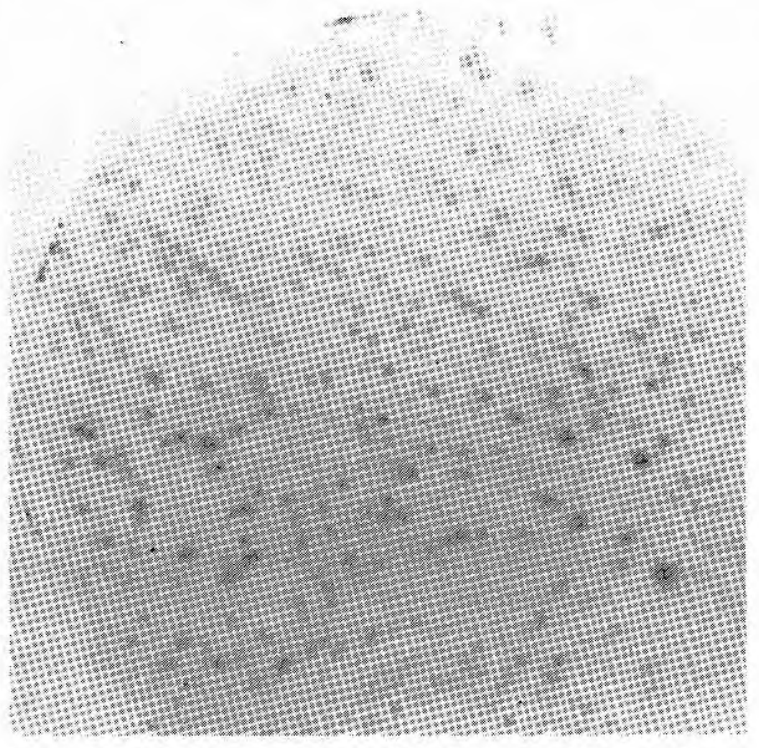

Figura 4. Fotografía correspondiente a una autorradiogratıa de uno de los clonos de PFCOL692 aislado y reconfirmado. Todas las placas de la caja corresponden al mismo clón.

lación. El hecho de que se clonen fragmentos grandes de DNA nos permite la clonación de genes incluyendo sus secuencias codificadoras y reguladoras. Todo lo anterior hace de la genoteca construida una herramienta útil en el estudio de la biología molecular del parásito.

\section{SUMMARY}

A Plasmodium falciparum genomic library was constructed in the vector EMBL-4 Lambda phage. It was screened with REP692a Plasmodium falciparum repetitive fragment which was previously cloned in plasmid pUC18. Twenty eight clones were isolated. The methodology both for construction of the library and for isolation of clones are described, and the importance of the library for further studies of the parasite's DNA structure is discussed. Keywords: Plasmodium, repetitive DNA, PFCOL692.

\section{AGRADECIMIENTOS}

Este trabajo fue financiado por el Instituto para el Desarrollo de la Ciencia y la Tecnología Francisco José de Caldas, Colciencias, y la Agencia Japonesa de Cooperación Internacional, JICA. 


\section{REFERENCIAS}

1. Aslund L, Franzen L, Westin G, et al. Highly reiterated non-coding sequence in the genome of Plasmodium falciparum is composed of 21 base-pair tandem repeats. J. Mol. Biol. 1985; 185:509.

2. Waters A, McCutchan T. Rapid sensitive diagnosis of malaria based on ribosomal RNA. Lancet 1989: 1:1343.

3. Mantilla R, Wasserman M. Tesis de Magister: Construcción de una biblioteca genómica de Plasmodium falciparum e identificación de clones por hibridización. Universidad Nacional de Colombia, Santafé de Bogotá, 1988.

4. López AE, Acosta H, Wasserman M. Tesis de pregrado: Caracterización de fragmentos genómicos de Plasmodium falciparum generados con la enzima de restricción Eco RI y clonados en el plásmido pUC18. Universidad Nacional de Colombia, Santafé de Bogotá, 1989.

5. Caminos E, Wasserman M. Tesis de pregrado: Separación de los cromosomas de $P$. falciparum utilizando la técnica de electroforesis de campo pulsado y ubicación del gen de la calmodulina con sondas marcadoras específicas. Universidad Nacional de Colombia, Santafé de Bogotá, 1991.

6. Kemp DJ, Coppel RL, Anders RF. Repetitive proteins and genes of malaria. Ann. Rev. Microbiol. 1987; $41: 181$.

7. Oquendo $P$, Goman M, Mackay M, et al. Characterisation of a repetitive DNA sequence from the malaria parasite, Plasmodium falciparum. Mol. Biochem. Parasitol. 1986; 18:89.

8. Chen G, Zhu J, Plitt JR, et al. A Plasmodium falciparum-specific reverse target capture assay. Mol. Biochem. Parasitol. 1991; 44:165.

9. Saúl A, Yeganeh F, Howard RJ. Clening and characterisation of a novel multicopy, repetitive sequence of Plasmodium falciparum, REP51. Immunol. Cell Biol. 1992; 70:357.

10. Trager W, Jensen JB. Human malaria parasites in continuous culture. Science 1976; 193:673.

11. Goman M, Langsley G, Hyde J, et al. The establishment of genomic DNA libraries for the human malaria parasite Plasmodium falciparum and identification of individual clones by hybridisation. Mol. Biochem. Parasitol. 1982: 5:391.

12. Ausubel F, Brent R, Kingston R, et al. Currents protocols in molecular biology. New York: John Wyley and Sons, 1991.

13. Frischauf A, Lehrach H, Poustka A, et al. Lambda replacement vectors carrying polylinker sequences. J. Mol. Biol. 1983; 170:827.

14. Rickwood D, Hames BD. Centrifugation: a practical approach.Oxford: IRL press, 1984.

15. Dugaizyk A, Boyer H, Goodman $\mathbf{H}$. Ligation of EcoR endonuclease generated DNA fragments into linear and circular structures. J. Mol. Biol. 1975; 96:171.

16. Perbal B. A practical guide to molecular cloning. New York: John Wiley and Sons, 1988, 394.

17. Honh B, Murray K. Packaging recombinant DNA molecules into bacteriophage particles in vitro. Proc. Natl. Acad. Sci. USA 1977; 74:3259.

18. Sambrook J, Fritsch EF, Maniatis T. Molecular cloning: a laboratory manual. New York: Cold Spring Harbor Laboratory press, 1989.

19. Benton W, Davis R. Screening gt recombinant clones by hibridisation to single plaques in situ. Science 1977; 196:180.

20. Feinberg AP, Vogelstein B. A technique for radiolabeling DNA restriction endonuclease fragments to high specific activity. Anal Biochem 1984; 137:266. 